\title{
Factors Affecting Voluntary Information Disclosure on Annual Reports: Listed Companies in Ho Chi Minh City Stock Exchange*
}

\author{
Thi Mai Huong NGUYEN**, Ngoc Tien NGUYEN"*** Hong Thu NGUYEN**** \\ Received: January 17, 2020 Revised: January 30, 2020 Accepted: February 06, 2020.
}

\begin{abstract}
The study aims to provide some plausible explanation for why Vietnamese listed companies only stop at the level of truthful presentation of information related to accounting data through the opinion of independent auditors. The information is only at the level of compliance with the requirements of Circular 155/2015/TT-BTC in form, but in essence is sketchy. What factors affect the level of voluntary disclosure of listed companies in Vietnam? In order to identify the factors affecting voluntary information disclosure on annual reports of listed companies, the study collected data on annual reports of 122 companies listed on the stock market in Ho Chi Minh City in the period 2015-2018 and uses regression analysis methods. The research presents 8 factors affecting the level of voluntary information disclosure including: Firm size, Listed time, Profitability, Solvency, Separation of board of directors and executive director, Board size, Organizational ownership and Foreign ownership. Next, the study conducted descriptive statistical analysis correlation coefficient analysis to examine the correlation and relevance of independent variables measured by the scale ratio, testing multiple linear regression model. The results of the study show that factors listed time, profitability and organizational ownership affecting voluntary information disclosure on annual reports of listed companies in Vietnam.
\end{abstract}

Keywords: Voluntary Information, Annual Report, Information Disclosure, Listed Company, Vietnam

JEL Classification: M41, M14, G32, G40

\section{Introduction}

The information disclosure is understood as a way to implement the transparent process of enterprises to ensure that shareholders and the investors can access information fairly and simultaneously. The information disclosure means that organizations participating in the securities market must be obliged to provide adequate, truthful and timely information relating to their operations or the market

\footnotetext{
*The authors would like to thank the anonymous referees for constructive comments on earlier version of this paper

${ }^{* *}$ First Author. Lecturer, Faculty of Accounting, Banking University of Ho Chi Minh City. Email: huongntm@buh.edu.vn

${ }^{* * *}$ Corresponding Author. Lecturer, Faculty of Economics and Accounting, Quy Nhon University, Binh Dinh, Vietnam [Postal Address: 170 An Duong Vuong, Quy Nhon City, Binh Dinh Province, 55000, Vietnam]. Tel: +0840905041179.

Email: nguyenngoctien@qnu.edu.vn

****Lecturer, Thu Dau Mot University, Binh Duong, Vietnam. Email: thunh@tdmu.edu.vn

() Copyright: The Author(s)

This is an Open Access article distributed under the terms of the Creative Commons Attribution NonCommercial License (https://creativecommons.org/licenses/by-nc/4.0/) which permits unrestricted noncommercial use, distribution, and reproduction in any medium, provided the original work is properly cited.
}

to stakeholders. The requirement of investors for the information disclosure is increasingly higher, not only in mandatory information disclosure, but also in voluntary information disclosure. Recently, the issue of voluntary disclosure is more interested by investors. According to Nguyen and Hoang (2012), voluntary information disclosure is a rather abstract concept, that in addition to the required information to be disclosed according to regulations, the manager must take the initiative in widely publicizing information related to the financial situation, strategic information as well as non-financial information of enterprises.

According to Schuster and O'Connell (2006), the voluntary information disclosure is very important in improving the quality of information disclosure, showing the future value and true value of the enterprises. The advantages of disclosing sensitive information to explain large investments; enhance the reputation of enterprises, etc. The information that enterprises need to publish above is presented mainly on the reports: Financial reports, Annual reports, Prospectus, Reports to the Annual Shareholders' Council, etc. According to the us, the most informative and diverse report, giving the overview of a company, is the 
annual report. Because this report provides not only financial information but also non-financial information, both current and future information, both quantitative and qualitative information, information about leaders and employees, customers, stakeholders, etc. Accordingly, the report for the manager to voluntarily disclose information in the most conveniently and appropriately way is the annual report . For many users in developed and developing countries, annual reports are considered the most important, most often and the source of the most authentic information in all other sources (Tian \& Chen, 2009).

Annual reports, sustainable development reports of businesses with good quality, meeting the requirements of regional and international standards, gradually helping to upgrade the market according to MSCI (Morgan Stanley Capital International) standards. In several years, Vietnam's stock market in general and Ho Chi Minh City's stock market in particular have developed strongly. In addition to the requirements for mandatory information to be disclosed, the issue of voluntary information disclosure of listed companies is very interested, so since the first circular guiding the announcement on stock market to be promulgated in 2004 (Circular 57/2004/TT-BTC), until now, the management agency has issued 4 substitute circulars in 2007 (Circular 38/2007/TT-BTC), 2010 (Circular 09/2010/TT-BTC), 2012 (Circular 52/2012/TT-BTC) and 2015 (Circular 155/2015/TT-BTC). This proves that the information disclosure requirements are now more being focused. Investors and shareholders do not just stop demand on enterprises to provide mandatory information but also voluntary information.

However, Vietnamese listed companies only stop at the level of truthful presentation of information related to accounting data, through the opinion of independent auditors. The information is only at the level of compliance with the requirements of Circular 155/2015/TT-BTC in form, but in essence is sketchy. So why there is a regulation on information disclosure on the stock market but do enterprises still not comply well with this? Which factors affect the level of voluntary disclosure of listed companies?

\section{Literature Review}

According to Li and Zhao (2011), the factors that affect the level of voluntary information disclosure of an enterprise is spent in two large groups: internal factors and external factors. In which, the internal factors such as: financial conditions of the company, ownership structure, independent board of directors, separating the chairman of the board of directors and executive director, etc.; External factors: the control of regulatory agencies, the opinion of independent auditors, the development of regional economy, industrial competition, etc.

The consideration of factors affecting the level of voluntary information disclosure has been made and published by many researchers. On the basis of background theory and inheritance of previous studies, namely the study of Barako (2007) conducted in Kenya or the study of Nguyen and Nguyen (2014) studied at the Ho Chi Minh City Stock Exchange (HOSE), etc; We gives a list of factors affecting the level of voluntary information disclosure and develop's research hypotheses corresponding to each factor in the research model as follows:

\section{Firm Size (OMDN)}

According to Barako (2007) and Baimukhamedova, Baimukhamedova, and Luchaninova, (2017), revenue scale affects the level of voluntary information disclosure due to:

- Derived from the theory of advantages in scale of production and information storage.

- Pressure from competition.

- Direct costs for information disclosure are a pressure on small companies.

- Large companies have large need for capital and have to raise more capital.

Large-scale enterprises need to use a variety of capital to invest and regulate operations. In order to do this, large enterprises need to be transparent financial information, financial reports must be audited by reputable auditing companies, build an accounting apparatus in good enterprises to improve quality of accounting information in financial statements, annual reports to reinforce investors' confidence in financial statements to attract investment capital. Since then, the research hypothesizes:

H1: The larger firm size is, the higher level of voluntary disclosure is.

\section{Listed Time (TGNY)}

According to Raffournier (1995), listed companies will disclose more information than unlisted enterprises for two reasons: Firstly, listed companies must comply with the minimum disclosure requirements of management agencies market; Secondly, in addition to publishing mandatory information, listed companies may also voluntarily provide additional information to increase investor confidence and thus obtain better financial conditions. Cooke (1991) shows that the level of disclosure in annual reports may vary according to listing status or Firth (1979) also points out that the minimum disclosure requirement of a listed stock market is slightly higher than that of unlisted firms.

At the same, according to Galani, Gravas, and 
Stavropoulos (2011), perennial listed and operating enterprises have the opportunity to improve the actual conditions for the reporting process, technology, and information disclosure costs. At the same time, enterprisesalso have many achievements to report to increase the reputation of the enterprise. For young enterprises, information disclosure will negatively affect the competitive position of the enterprises in the market. Since then the research hypothesizes:

H2: The longer listed time is, the higher level of voluntary disclosure is.

\section{Profitability (KNSL)}

According to agency theory, if enterprises operate effectively, themanagers will proactively disclose more information to agree on their reward levels (Singhvi \& Desai, 1971) as well as enhance their value in labor market (Barako, 2007). At the same time, high profitability impacts the stock price on the stock market. However, in the reverse view, the enterprises who do not well operate will also publish much to explain the situation of the company to shareholders. Since then, the research needs to verify the contrary views with the following hypothesis:

H3: The higher profitability of an enterprise is, the higher level of voluntary disclosure is.

\section{Solvency (KNTT)}

Experimental studies show that there are two opposite points of view: (i) The higher the solvency is, the more active the enterprise is to publish information to demonstrate the operational well-being of enterprises (Singhvi, 1968 ); and (ii) Low solvency, enterprises tend to publish as much as possible to justify company status with external audiences (Wallace, Naser, \& Mora, 1994). Thus, the research makes assumptions to verify as follows:

H4: The higher solvency is, the higher the level of voluntary disclosure is.

\section{Separation of Executive Director and Chairman of the BOD (TBQTGD)}

According to agency theory, the concurrent significantly reduces the control role and increases the ability to agree on bonus levels for senior executives (Barako, 2007). In addition, concurrently people easily dominate power, perform opportunistic and harmful acts for other shareholders. Therefore, the research hypothesizes:

H5: The enterprise separated the title of Chairman of the Board of Directors from the executive director leads to the the higher level of voluntary disclosure.

\section{Board Size (QMHDQT)}

The larger the number of members of the board is, the higher the capacity is to control, make decisions and avoid the concentration of power on a few key figures. Thus, the interests of shareholders who are not present in the board are protected at a higher level, from which the level of disclosure will increase. The larger the scale of the board is, the more powerful in many aspects to help improve the efficiency of the company. On the other hand, the more monitoring function is enhanced, the more managers will try to publish information about the company situation. However, it is not enable to increase the number of members of the board as much as possible because its depends on the size of the company, the field of operation to ensure the cost and the benefits that the board of directors value brought to the company. Therefore, according to the corporate governance law of many countries, it usually stipulates the minimum and maximum number of members of the board. In Vietnam, Clause 1, Article 13 of Decree 71/2017/ND-CP provides guidance on corporate governance for general companies which stipulates that "The minimum members of the Board of Directors is at least three (03) people and maximum is eleven (11) people". The research of Sweiti and Attayah (2013), Chakroun and Matoussi (2012) show that the size of the board has the same impact on the level of voluntary disclosure. Since then, the research hypothesizes:

H6: The larger board size is, the higher level of voluntary disclosure is.

\section{Foreign Ownership (QSHNN)}

Foreign investors always have high caution due to the geographical and cultural isolation between owners and administrators. This gap should be offset by an increase in the level of disclosure. To reach and satisfy these objects, the company must increase its disclosure (Singhvi, 1968). There are many previous studies show that the larger part of foreign-owned the companies have, the more information is published. Barako (2007) found that the factor of foreign ownership is very important for the level of information disclosure. The research of Hossain, Perera, and Rahman (1995) found the same dimensional relationship between foreign ownership with the voluntary disclosure of companies in New Zealand. Similarly, Barako, Hancock, and Izan (2006) also found a positive relationship between foreign ownership and the level of voluntary disclosure. Since then, the research hypothesizes:

H7: The higher foreign ownership rate is, the higher level of voluntary disclosure is. 


\section{Organizational Ownership (QSHTC)}

The state when owning capital in the company will impose a strict supervision mechanism. Therefore, there is a positive relationship between state ownership and financial information disclosure. In the Czech Republic, the government has chosen to hold more shares in companies considered important in the nation, because of the great interest from the public to these companies, the research results show that level of voluntary disclosure by companies that the government holds is very high (AlJanadi, Rahman, \& Omar, 2013). Since then, the research hypothesizes:

H8: The higher organizational ownership rate is, the higher level of voluntary disclosure is.

Based on the factors identified and coded, we builds a model to study the factors affecting the level of voluntary information disclosure with the following linear regression form:

CBTTTN $=\beta_{0}+\beta_{1} \mathrm{QMDN}+\beta_{2} \mathrm{TGNY}+\beta_{3} \mathrm{KNSL}+$ $\beta_{4}$ KNTT $+\beta_{5}$ TBQTGD $+\beta_{6}$ QMHDQT $+\beta_{7}$ QSHNN + $\beta_{8}$ QSHTC $+\mathrm{U}_{\mathrm{i}}$

In which:

$\beta_{0}$ : Regression constant

$\beta_{1}$ : Regression coefficient

\section{$\mathrm{U}_{\mathrm{i}}$ : Random error}

\section{Research Methods}

\subsection{Measurements}

In this study, with "dependent variable", we uses unweighted measurement method because this method has many advantages to express objectivity. At the same time, many previous empirical studies such as Coombs and Tayib (1998) and Cooke (1992) have shown no difference in research results between these two measures.

$$
Y j=\frac{1}{n} \sum_{i=0}^{n}(\mathrm{dij})
$$

In which:

$\mathrm{d}_{\mathrm{ij}}$ : equals 1 if the information element $\mathrm{i}$ is published in the annual report of the enterprise $j$.

$\mathrm{d}_{\mathrm{ij}}$ : equals 0 if the information element $\mathrm{i}$ is not published

$\mathrm{n}$ : maximum number of information elements can be disclosed in the enterprise

Measuring independent variables in this study model, author inherits many previous studies such as Nguyen and Nguyen (2014). Statistical authors and synthesized in Table 1 below:

Table 1: Measurement of independent variables in the model

\begin{tabular}{|c|c|c|c|c|c|}
\hline No. & Variable name & Encode & Measure & Source & Expected \\
\hline 1 & Firm size & QMDN & $\begin{array}{c}\text { Log Total assets at the end of the } \\
\text { year }\end{array}$ & $\begin{array}{c}\text { Klai and Omri (2011), } \\
\text { Baimukhamedova et al. } \\
\text { (2017) }\end{array}$ & + \\
\hline 2 & Listed time & TGNY & Number of years listed on HOSE & $\begin{array}{l}\text { Nguyen and Nguyen } \\
\text { (2014) }\end{array}$ & + \\
\hline 3 & Profitability & KNSL & $\begin{array}{l}\text { Profit after } \\
\text { tax/ Total assets }\end{array}$ & $\begin{array}{l}\text { Ta (2012), Tahir et al. } \\
\text { (2016), Nguyen and } \\
\text { Nguyen (2019) }\end{array}$ & + \\
\hline 4 & Solvency & KNTT & $\begin{array}{c}\text { Short-term assets/ Short-term } \\
\text { debts }\end{array}$ & Lan et al (2013), & + \\
\hline 5 & $\begin{array}{l}\text { Separation of chairman of } \\
\text { BOD and executive director }\end{array}$ & TBQTGD & $\begin{array}{l}\text { Dummy Variable } \\
0: \text { There is no separation } \\
\text { 1: There is separation }\end{array}$ & Klai and Omri (2011) & - \\
\hline 6 & Board size & QMHDQT & Number of members in the Board & Klai and Omri (2011) & + \\
\hline 7 & Foreign ownership & QSHNN & $\begin{array}{l}\text { Number of common shares held } \\
\text { by foreign shareholders/ Total } \\
\text { common shares }\end{array}$ & Klai and Omri (2011) & + \\
\hline 8 & Organizational ownership & QSHTC & $\begin{array}{c}\text { Number of ordinary shares held } \\
\text { by the organization/ Total common } \\
\text { shares }\end{array}$ & Klai and Omri (2011) & + \\
\hline
\end{tabular}




\subsection{Data}

We selects the inherited independent variables of the research of Barako (2007) relates to the level of voluntary information disclosure. Besides, we compares the list of public voluntary information inherited from Ta (2012) and Circular no. 155/2015/TT-BTC to provide the official list of voluntary information disclosure index. To measure the dependent variable "voluntary information disclosure" and independent variables, in this study, the author inherited the use of scales from previous studies: Coombs and Tayib (1998) and Cooke (1992).

In the us paper, there are 8 independent variables, so the minimum sample size is 114 observed. Accordingly, we will conduct a minimum sample of 114 enterprises on the HOSE to measure dependent variables and independent variables. These will exclude enterprises in the field of banks, securities, investment funds, insurance funds. Because these enterprises, in addition to complying with securities laws, corporate governance regulation, they must also operate under the Law on Credit Institutions and other relevant laws.

We only collects data on the annual report of the companies registering for securities trading by the time of December 31, 2018 and provides sufficient annual reports in period 2015 - 2018 on the website https://www.hsx.vn. Data collected of the enterprises include: Total assets, Listed time, Profitability/ total assets ratio, Short-term solvency index, Separation of board of directors and board of management, Board size, Foreign ownership rate, Organizational ownership rate. After being collected by the us, the data will be imported and processed by Excel 2013 software before running quantitatively with STATA software.

\subsection{Empirical Model}

To analyze the factors affecting level of voluntary disclosure of listed enterprises, we uses descriptive statistical methods and quantitative methods. Research build a panel data through combining data series over period from 2015 to 2018 of spatial observations (listed companies). The common regression method with panel data is Pooled OLS Regression Model, fixed impact model (Fixed Regression Model Effects - FEM) and random impact model (Random Effects Regression Model - REM). Models using panel data are often estimated by the general panel data model as follows:

$$
\mathrm{Y}_{\mathrm{it}}=\beta_{1}+\beta_{2} \mathrm{X}_{2 \mathrm{it}}+\beta_{3} \mathrm{X}_{3 \mathrm{it}}+\ldots . .+\beta_{\mathrm{n}} \mathrm{X}_{\mathrm{nit}}+\mathrm{U}_{\mathrm{it}}
$$

In which, $\mathbf{U}_{\mathbf{i t}}$ is the error combination of models and $\mathbf{U}_{\mathbf{i t}}$ $=\mathbf{v}_{\mathbf{i}}+\mathbf{e}_{\mathbf{i t}}$. In this combined error, $\mathbf{v}_{\mathbf{i}}$ is considered to be the specific effects of each unit $i$ without changing over time, while $\mathbf{e}_{\mathbf{i t}}$ is the random variable that appears in the error. There are two problems should be handled models: $\mathbf{v}_{\mathbf{i}}$ impact on the independent variable and $\mathbf{e}_{\mathbf{i t}}$ autocorrelation. Since $\mathbf{v}_{\mathbf{i}}$ is a component of the error and it can affect independent variables $\mathrm{X}$. If this happens, it makes the estimation deviate. Therefore, testing whether or not $\mathbf{v}_{\mathbf{i}}$ effect on the independent variable will determine the appropriate model of estimation. Like wise for $\mathbf{e}_{\mathbf{i t}}$. If $\mathbf{v}_{\mathbf{i}}$ have an impact on the independent variable while $\mathbf{e}_{\mathbf{i t}}$ is not correlated, the appropriate estimation method is a fixed effect (FEM). If $\mathbf{v}_{\mathbf{i}}$ have no impact on the independent variable while $\mathbf{e}_{\mathbf{i t}}$ is autocorrelation, the appropriate estimation method is random effect (REM). In case of $\mathbf{v}_{\mathbf{i}}$ have no impact on the independent variable and $\mathbf{e}_{\mathbf{i t}}$ is not correlated, the appropriate estimation method is Pooled OLS. To choose between FEM, REM, Pooled OLS researcher often uses Hausman test (1978). This test helps us to choose the model according to FEM or REM. If the result is according to FEM, then stop the selection and then make the estimates as well as the necessary model tests. If the selection is according to REM, the choice between REM and Pooled OLS should be continued by testing the largrange factor.

In addition, the estimation results are reflected by the omission of individual characteristics (Gujarati, 2004), the possibility of autocorrelation in the data is quite high or binding the residuals which make value of Durbin - Wason low. Therefore, although this is a simple case, this regression model can distort the actual relationship between the dependent variable and the independent variables.

\section{Research Results}

\subsection{Descriptive Statistics}

Descriptive statistics by calculations and statistical indicators will generally show a overview of the basic characteristics of variables in the research sample. With the results obtained from research data, including: Maximum value, Minimum value, Average value, Standard deviation and Number of observations (see Table 2 and Figure 1).

Through Table 2 and Figure 1, the group of information mostly published by enterprises is "Forecast/Plan information", with the average over the years respectively $52,69 \%, 54,92 \%, 54,45 \%$ and $53,98 \%$ of enterprises announced this information group. Next is the "Executive board information" and "Information related to employees" announced by the enterprises with nearly equal proportions. Among information groups, the Forecast/Plan information group is the most published by enterprises, in which information on sales/consumption volume and future profit 
are the two information that many public enterprises announced the most because these are the targets of planning and forecasting enterprises can implement in the coming time, so it is necessary to have information for investors to determine the future of enterprises before they decide to invest. The group of "Financial Information" and "General information about enterprises" is published by few enterprises. Regarding financial information, this is sensitive information, so few enterprises announce it. In addition, usually enterprises will publish the main financial information of the business in the last two years of operation to compare the performance of targets against the proposed plan. Few enterprises publish summary financial data for at least three years. For general information, not many enterprises announced. However, the general information in the voluntary information disclosure checklist of this study also has many sensitive information such as: Market share of enterprises, Declaration of competitive advantages, Quality control standards quality, Comment on important business relationships, etc; so the results show that many enterprises also avoid publishing this information.

Table 2: Statistics describing level of voluntary disclosure

\begin{tabular}{|c|c|c|c|c|c|}
\hline Variable name & Maximum value & Minimum value & Average value & Standard deviation & Number of observ. \\
\hline \multicolumn{6}{|c|}{ Dependent variable } \\
\hline CBTTTN & 0,6364 & 0,0909 & 0,3551 & 0,1178 & 488 \\
\hline \multicolumn{6}{|c|}{ Independent variables } \\
\hline QMDN & 14,4593 & 10,6922 & 12,2823 & 0,6169 & 488 \\
\hline TGNY & 18,0000 & 0,0000 & 7,8832 & 3,2822 & 488 \\
\hline KNSL & 0,5231 & $-0,3523$ & 0,0723 & 0,0814 & 488 \\
\hline KNTT & 34,8501 & 0,3400 & 2,4175 & 3,3117 & 488 \\
\hline TBCTGD & 1,0000 & 0,0000 & 0,7664 & 0,4236 & 488 \\
\hline QMHDQT & 11,0000 & 3,0000 & 5,9590 & 1,3768 & 488 \\
\hline QSHNN & 0,9411 & 0,0000 & 0,1771 & 0,1766 & 488 \\
\hline QSHTC & 0,9670 & 0,0000 & 0,3654 & 0,2696 & 488 \\
\hline
\end{tabular}

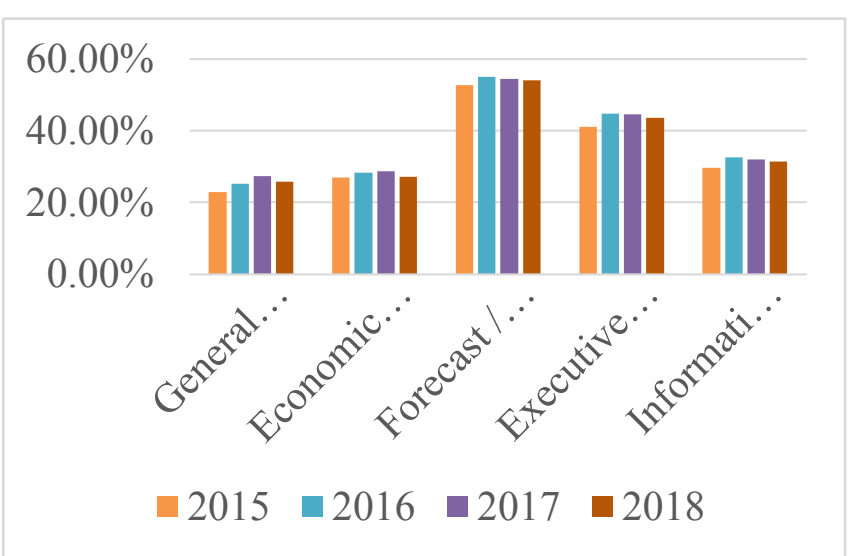

Figure 1: Level of voluntary information disclosure by information group

In general, level of voluntary disclosure of enterprises on HOSE is still relatively. Small enterprises, newly listed often provide sketchy information, there is no investment, avoidance of information relating to the financial situation, business, information provided is based on compulsory contents according to the new annual report form, have not shown the responsibility to provide information for users as a basis for decision making. However, there are also many companies that have shown their investment in presenting annual reports in a very sufficient, rich and diverse way. Not only fully present the compulsory content of an annual report in detail but also add diverse voluntary information during the operation of the business.

\subsection{Testing the Research Model}

\subsubsection{Correlation}

To test the possibility of a multicollinearity phenomenon between variables in the model, the study uses the correlation coefficient matrix between the variables used for analysis. Through the use of the correlation coefficient matrix between pairs of variables will form the basis for the observation of correlation relationships. Gujarati (2004) argued that correlation coefficients between variables exceeding 0,8 would indicate that the model is likely to experience serious multicollinearity problems. Then, the sign of regression coefficients in the model can be changed, leading to the false results for the study. Therefore, the study mainly pay attention to the relationship between variables with correlation coefficient of 0,8 or more 
(relatively close correlation).

The results of testing the correlation between variables in this study model are shown in Table 3. Observing data table, we find that the independent variables are highly correlated with the dependent variables: QMDN, KNSL, TBCTGD, QMHDQT, QSHNN. For independent variables, QMHDQT and QSHNN are most correlated with each other at 0,3575.
However, this level is still lower than 0,8 so there is no multicollinearity phenomenon. The remaining pairs of variables in the data table show that the probability of occurrence of multicollinearity in the regression model is not large because the correlation coefficients between variables have no cases of absolute value exceeding 0,8 .

Table 3: Correlation matrix

\begin{tabular}{|c|c|c|c|c|c|c|c|c|c|}
\hline .corr CBTTTI & QMDN & TGYN KNSL & KTTT & TBCTGD QI & QSH & QSHTC & & & \\
\hline & CBTTTN & QMDN & TGYN & KNSL & KNTT & TBCTGD & QMHDQT & QSHNN & QSHTC \\
\hline CBTTTN & 1.0000 & & & & & & & & \\
\hline QMDN & 0.2335 & 1.0000 & & & & & & & \\
\hline TGNY & -0.0174 & 0.0624 & 1.0000 & & & & & & \\
\hline KNSL & 0.2189 & -0.0305 & -0.0191 & 1.0000 & & & & & \\
\hline KNTT & 0.0371 & -0.1559 & -0.1317 & 0.2274 & 1.0000 & & & & \\
\hline TBCTGD & 0.2016 & 0.0270 & 0,0128 & 0.1803 & -0.0024 & 1.0000 & & & \\
\hline QMHDQT & 0.2045 & 0.3341 & 0.1107 & 0.1011 & -0.0103 & 0.0434 & 1.0000 & & \\
\hline QSHNN & 0.2976 & 0.3263 & 0.1548 & 0.3284 & 0.0934 & 0.0275 & 0.3575 & 1.0000 & \\
\hline QSHTC & 0.0688 & -0.1108 & -0.0332 & 0.0878 & -0.0504 & 0.3441 & -0.1472 & -0.2714 & 1.0000 \\
\hline
\end{tabular}

\subsubsection{Testing the Regression Model}

\section{Multicollinearity}

The correlation coefficient shows us the first signs of the possibility of multicollinearity, which is not sufficient to conclude that the model have multi-collinear or not. Because, the correlation coefficient cannot detect the correlation between a variable and a variable group. Therefore, to ensure that the phenomenon of multi-collinear not occur between variables, the researchcontinue to test the Variance Inflation Factor (VIF) in Table 4:

Table 4: Variance Inflation Factor (VIF)

\begin{tabular}{|c|c|c|}
\hline No. & Variable name & VIF \\
\hline 1 & Foreign ownership (QSHNN) & 1,53 \\
\hline 2 & Organization ownership (QSHTC) & 1,28 \\
\hline 3 & Profitability (KNSL) & 1,26 \\
\hline 4 & Firm size (QMDN) & 1,26 \\
\hline 5 & Board size (QMHDQT) & 1,23 \\
\hline 6 & Separation of chairman of BOD and executive & 1,18 \\
\hline 7 & director (TBCTGD) & 1,11 \\
\hline 8 & Solvency (KNTT) & 1,05 \\
\hline
\end{tabular}

According to Gujarati (2004), if VIF is less than 5, there is no multicollinearity phenomenon, VIF is greater than 10 , then conclude that the model is multicollinear. However, the fact that previous studies have suggested independent variables with VIF $>3$ should be considered carefully when included in the model. As a result, Table 4 shows that all variables in the model have $\mathrm{VIF}<2$, so it is possible to confirm that the model does not occur multicollinearity phenomenon.

\section{Heteroscedasticity}

According to Hoang and Chu (2008), if the research model has an "error variance" changes, it makes estimates of regression coefficients not biased but not the most appropriate estimate, verifying invalid hypotheses makes us misjudge the quality of the linear regression model. Therefore it is necessary to test the error variance. This study uses Wald test to test the error variance for this fixed effects model. We based on Prob $>$ chi2 coefficient, if Prob $>$ chi2 is larger than $5 \%$ belongs to the acceptance area $\mathrm{H}_{0}$ : "The model does not suffer from heteroscedasticity".]

The Wald test results in Table 5 show that Prob $>$ chi2 $=$ $0,0000<5 \%$, in the rejecting area $\mathrm{H}_{0}$ : "The model does not suffer from heteroscedasticity". It means that there is a phenomenon of heteroscedasticity in the models with dependent variable CBTTTN. Thus, the regression model estimated by FEM method does not guarantee the assumption. The study will overcome these two errors by Robust standard error.

Table 5: Results of heteroscedasticity test

\begin{tabular}{|l|r|}
\hline Chi2 & 400,000 \\
\hline Prob $>$ chi2 & 0,0000 \\
\hline
\end{tabular}




\section{Testing the Hypotheses}

The results of the multiple linear regression equation test or the test of the relationship between the independent variables on dependent variable summarized in the following (see Table 6):

Table 6: Results of multiple linear regression equations

\begin{tabular}{|l|c|c|c|c|}
\hline \multicolumn{1}{|c|}{ Model } & $\boldsymbol{\beta}$ & $\begin{array}{c}\text { Standard } \\
\text { deviation }\end{array}$ & $\mathbf{T}$ & P>t \\
\hline QMDN & 0,010 & 0,009 & 1,140 & 0,258 \\
\hline TGNY & 0,004 & 0,002 & 2,060 & 0,041 \\
\hline KNSL & 0,076 & 0,045 & 1,710 & 0,090 \\
\hline KNTT & 0,001 & 0,001 & 0,460 & 0,648 \\
\hline TBCTGD & 0,013 & 0,019 & 0,690 & 0,491 \\
\hline QMHDQT & 0,005 & 0,003 & 1,580 & 0,116 \\
\hline QSHNN & $-0,044$ & 0,083 & $-0,530$ & 0,600 \\
\hline QSHTC & $-0,056$ & 0,019 & $-2,820$ & 0,006 \\
\hline Constant & 0,179 & 0,107 & 1,67 & 0,098 \\
\hline
\end{tabular}

As the analysis results, there are 3 independent variables that affecting dependent variable CBTTTN including: TGNY, KNSL, QSHTC. Since these variables have significance levels of regression coefficients $\mathrm{P}>|\mathrm{t}|$ respectiv ely 0,$041 ; 0,090 ; 0,006<0,1$ prove that hypothesis $\mathrm{H}_{0}$ : $\beta_{\mathrm{i}}=0$ "The independent variable $\mathrm{i}$ does not have a linear relationship with the dependent variable" rejected with reliability $95 \%$. In which, TGNY and KNSL have a positive impact on the dependent variable because of the coefficient $\beta>0$. Besides, QSHTC having the opposite effect with the dependent variable because of the coefficient $\beta<0$. Based on weighted regression, we also see the variable KNSL have $\beta \beta$ $\mid=0,076$ is the largest compared to the remaining two variables so that KNSL has the strongest impact on CBTTTN, next is QSHTC and the lowest is TGNY.

With the data set collected within the research scope of the topic and based on the results of analysis in $\mathrm{T}$ able 6, multiple regression equation shows factors affec ting level of voluntary information disclosure in the fol lowing form:

CBTTTN $=0,179+0,004 * \mathrm{TGNY}+0,076 * \mathrm{KNSL}-$ $0,056 * \mathrm{QSHTC}+\mathrm{U}_{\mathrm{i}}$

\section{Results and Discussion}

The objective of this research is to measure factors affecting level of voluntary disclosure on the annual report of enterprises listed on HOSE. From that, make recommendations to improve level of voluntary disclosure of listed enterprises. To address the research objectives and questions, the research used panel data with 388 research data of 122 enterprises listed on HOSE in the period from 2015 to 2018, according to 3 regression analysis methods are Pooled OLS, FEM, REM with independent variables: Firm size (QMDN), Listed time (TGNY), Profitability (KNSL), Solvency (KNTT), Separation of chairman of BOD and executive director (TBCTGD), Board size (QMHDQT), Foreign ownership (QSHNN) and Qrganizational ownership (QSHTC).

In the process of running the model using F-test and Hausman test, we found that the fixed effects model (FEM) is a suitable model to consider the impact of independent variables to the level of voluntary information disclosure of non-financial listed companies on HOSE. However, the FEM model still has error variance. Therefore, we uses robust standard error to correct the quantitative model.

Through the regression analysis results, research model is completely suitable. The first question of te research has been solved: Average level of voluntary disclosure on annual reports of listed companies on HOSE 35,51\%; Maximum level of voluntary disclosure on annual reports of listed companies on HOSE is $63,64 \%$; In which, minimum is $9,09 \%$. Compared with previous research results, we research has quite similar results with the study of Elmans (2012) conducted a study of 100 companies, including five countries: Germany, France, Italy, Ha Lan and Belgium in 2010. The results show that the average level of voluntary information disclosure is $56,9 \%$, the highest is in Netherlands (67\%), followed by France $(63,5 \%)$, Germany $(57,3 \%)$, Belgium $(50,3 \%)$ and Italy $(46,3 \%)$. In addition, compared with the study of Nguyen (2014) when studying the level of voluntary information disclosure of listed companies on HOSE the highest level of voluntary disclosure according to this study is $59 \%$, the lowest is $3 \%$ and the average of $23,2 \%$, results of this study is higher. Factors affecting level of voluntary disclosure are: Listed Time, Profitability and Organizational ownership. In which, only Organizationa ownership is have opposite effect and remaining factors are the same impact on level of voluntary information disclosure. This result also solved question 2 of the research and research objective of this research is to find out factors which is affecting level of voluntary disclosure of enterprises listed on HOSE.

\section{Conclusion}

Although data were analyzed by both space and time, the sample requirements were met in quantitative analysis, but the fact that the studies performed by the us has a wide range is not yet covered both listed companies on Ho Chi Minh City and Hanoi Stock Exchanges. We has recently analyzed level of information disclosure within the scope of 
quantity, therefore, the next studies can measure the quality of accounting information disclosure or consider many aspects of the nature of published information in both quantity and quality. In addition, a limitation of the research is that it cannot cover all the factors affecting level of publication of enterprises that belong to the cultural, behavioral and qualification factors of managers and accountants in the enterprise.

\section{References}

Al-Janadi, Y., Rahman, R. A., \& Omar, N. H. (2013). Corporate Governance Mechanisms and Voluntary Disclosure in Saudi Arabia. Research Journal of Finance and Accounting, 4(4), 25-35.

https://pdfs.semanticscholar.org/78a9/b2f1c40016eb14c19f092 c52e919c18f5065.pdf

Barako, D. G. (2007). Determinants of voluntary disclosures in Kenyan companies annual reports. African Journal of Business Management, 1(5), 113-128.

https://pdfs.semanticscholar.org/1424/5cab9d7f031ffd10dfaab 22ed0d473924c98.pdf

Barako, D. G., Hancock, P., \& Izan, H. Y. (2006). Factors Influencing Voluntary Corporate Disclosure by Kenyan Companies, February 2006, Corporate Governance An International Review, 14(2), 107-125. DOI: 10.1111/j.14678683.2006.00491.x

Baimukhamedova, A., Baimukhamedova, G., \& Luchaninova, A. (2017). Financial Disclosure and the Cost of Equity Capital: The Empirical Test of the Largest Listed Companies of Kazakhstan. Journal of Asian Finance, Economics and Business, 4(3), 5-17. http://dx.doi.org/10.13106/jafeb.2017.vol4.no3.5

Chakroun, R., \& Matoussi, H. (2012). Determinants of the extent of Disclosure in the Annual reports of the Tunisian firms voluntary. Accounting and Management Information Systems, 3, 335-370. http://www.cig.ase.ro/articles/11_3_2.pdf

Cooke, P. (1992). Regional innovation systems: Competitive regulation in the new Europe. Geoforum, 23(3), 365-382. https://doi.org/10.1016/0016-7185(92)90048-9

Cooke, T. E. (1991). Environmental Factors Influencing Mergers and Acquisitions in Japan. Journal of International Financial Management \& Accounting, 3(2), 160-188. https://doi.org/10.1111/j.1467-646X.1991.tb00102.x

Coombs, H., \& Tayib, M. (1998). Developing a Disclosure Index for Local Authority. The Asian Pacific Interdisciplinary Research in Accounting Conference. Retrieved from http://citeseerx.ist.psu.edu/viewdoc/download?doi=10.1.1.198. $345 \&$ rep $=$ rep $1 \&$ type $=$ pdf

Elmans, S. (2012). Ownership structure and voluntary disclosure in Europe [Master thesis, Eramus University of Rotterdam].

Firth, M. (1979). The impact of size, stock market listing, and auditors on voluntary disclosure in corporate annual reports. Accounting and Business Research, 9(36), 273-280. https://doi.org/10.1080/00014788.1979.9729168

Galani, D., Gravas, E., \& Stavropoulos, A. (2011). Company Characteristics and Environmental Policy. Business Strategy and the Environment, 21(4), 236-247. doi:10.1002/bse.731.

Government of the Socialist Republic of Vietnam. (2017). Decree 71/2017/ND-CP dated June 6, 2017 of the Prime Minister on Guidance on corporate governance for public companies.

Gujrati, D. N. (2004). Basic Econometrics (4th ed.). New York, NY: The McGraw-Hill Companies.

Hausman, J. (1978) Specification Tests in Econometrics. Econometrica, 46, 1251-1271. https://doi.org/10.2307/1913827.

Hoang, T., \& Chu, N. M. N. (2008). Analysis of research data with SPSS. Ho Chi Minh City, Vietnam: Hong Duc Publishing House.

Hossain, M., Perera, M. H. B., \& Rahman, A. R. (1995). Voluntary Disclosure in the Annual Reports of New Zealand Companies. Journal of International Financial Management \& Accounting, 6(1), 69-87. Doi:10.1111/j.1467-646x.1995.tb00050.x.

Klai, N., \& Omri, A. (2011). Corporate Governance and Financial Reporting Quality: The Case of The Tunisian Firms. International Business Research, 4(1). doi:10.5539/ibr.v4n1p158.

Lan, Y., Wang, L., \& Zhang, X. (2013). Detereminants and feartures of voluntary disclosure in the Chinese stock market. China Journal of Accounting Research, 6(4), 265-285. https://doi.org/10.1016/j.cjar.2013.04.001

Li, H., \& Zhao, P. (2011). A study of factors influencing voluntary disclosure of Chinese listed companies. $M \& D$ Forum, 245257. Retrieved from https://pdfs.semanticscholar.org/424a/27c09b80e008a807a575 35e775bb408a5ac9.pdf

Ministry of Finance (2004). Circular 57/2004/TT-BTC guiding disclosure of information disclosure on the stock market.

Ministry of Finance (2007). Circular 38/2007/TT-BTC guiding disclosure of information disclosure on the stock market.

Ministry of Finance (2010). Circular 09/2010/TT-BTC guiding disclosure of information disclosure on the stock market.

Ministry of Finance (2012). Circular 52/2012/TT-BTC guiding disclosure of information disclosure on the stock market.

Ministry of Finance (2015), Circular 155/2015/TT - BTC of the Minister of Finance promulgating the Guidance on information disclosure on the stock market.

Nguyen, T. T. H. (2014). Factors affecting the voluntary level of information disclosure of listed companies on HOSE. Economic Development Journal, 26, 99-115.

Nguyen, C. D., \& Hoang, T. (2012). CEO and voluntary information disclosure of listed businesses. Course \& Application Journal, 18, 62 - 65.

Nguyen, C. P., \& Nguyen T. T. P. (2014). Factors affecting information disclosure activities of listed companies on Vietnam stock market. Economic Development Review, 287, 15-34.

Nguyen, T. N. L., \& Nguyen, V. C. (2019). The Determinants of Profitability in Listed Enterprises: A Study from Vietnamese Stock Exchange. Journal of Asian Finance, Economics and Business, 7(1), 47-58. https://doi.org/10.13106/jafeb.2020.vol7.no1.47

Raffournier, B. (1995). The determinants of voluntary financial disclosure by Swiss listed companies. European Accounting Review, 4(2), 261-280, DOI: 10.1080/09638189500000016

Schuster, P., \& O'Connell, V. (2006). The Trend toward Voluntary 
Corporate Disclosures. Management Accounting Quarterly, $7(2), 1-9$.

Singhvi, S. S. (1968). Corporate disclosure through annual reports in the united states of america and india. The Journal of Finance, 23(3), 551-552. doi:10.1111/j.15406261.1968.tb00838.x.

Singhvi, S. S., \& Desai, H. B. (1971). An empirical analysis of the quality of corporate financial disclosure. The Accounting Review, 46(1), 129-138.

Sweiti, I. M., \& Attayah, O. F. (2013). Critical Factors Influencing Voluntary Disclosure: The Palestine Exchange "PEX." Global Journal of Management and Business Research, 13(6C). Retrieved from https://www.researchgate.net/publication/-260795490

Ta, Q. B. (2012). Voluntary Disclosure Information in the Annual Reports of Non Fianancial List Companies: The Case of Vietnam. Journal of Applied Economics and Business
Research, 2, 69-90.

http://www.aebrjournal.org/uploads/6/6/2/2/6622240/2._binh2.pdf

Tahir, M., \& Mushtaq, M. (2016). Determinants of Dividend Payout: Evidence from Listed Oil and Gas Companies of Pakistan. Journal of Asian Finance, Economics and Business, 3(4), 25-37. https://doi.org/10.13106/jafeb.2016.vol3.no4.25

Tian, Y., \& Chen, J. (2009). Concept of Voluntary Information Disclosure and A Review of Relevant Studies. International Journal of Economics and Finance, 2, 55-59. DOI:10.5539/ijef.v1n2p55

Wallace, R. S. O., Naser, K., \& Mora, A. (1994). The relationship between the comprehensiveness of corporate annual reports and firm characteristics in Spain. Accounting and Business Research, 25(97), 41-53.

https://doi.org/10.1080/00014788.1994.9729927 